\title{
ON A NEW NEMATODE, CAPILLARIA STRIATA N.SP. FROM FRESH WATER FISH CHANNA STRIATUS (BLOCH)
}

\section{Rashmi Sao}

Govt. E. R. R. P.G. Science College, Bilaspur, (M.P.), India

Corresponding author Email : rashmi.sao@rediffmail.com

\begin{abstract}
:
Capillaria striata n.sp. was described from the intestine of a fresh water fish, Channa striatus (Bloch). It was distinguished from other congeneric species by spiny spicular sheath, mainly length of spicules (1.3-1.4) its surface covered by small spines and valvular lips not elevated.
\end{abstract}

Keywords:

Nematodes, fish parasite, biodiversity, Chhattisgarh, India

\section{Introduction:}

The aim of present study was to provide a current survey of the species of nematode parasites found in fishes of Chhattisgarh namely Bilaspur region.During a survey of nemotode parasites, several male and female specimens of the genus Capillaria Zeder, 1800, were recovered from the intenstine of the fresh-water fish, Channa striatus (Bloch), collected from the river Kharang crossing Village, Mohra (Bilaspur C.G.) of the several fishes disected only eight fishes harboured with nematode parasites. A detailed study of those worms revealed that they do not cofirm to any known species of the genus and appear to constitute a new species

\section{Material and Method:}

The host Channa striatus was obtained from river Kharang crossing the village Mohra, Distt. Bilaspur (C.G.). Fishes were examined thoroughly for nematode parasites. Out of 37 fishes examined, only 8 were infected, in these 3 males $\& 6$ females were observed. Nematodes were fixed in hot $70 \%$ alcohol and were preserved in $10 \%$ glycerol. Two clearing media, glycerol \& creosote were used in order to examine properly. All measurements are in millimetres. 


\section{Description:}

Male is smaller than female. Body long, mouth aperture small, oval surrounded by 6 minute cephalic papillae arranged in circlet. Oesophagus relatively long. divided into two parts, shorter anterior muscular oesophagus and a longer posterior glandular oe

\section{Result and Discussion:}

The present form when compared to known forms the following facts are observed : The new form Capillaria striata n.sp. differs from all the known species. Capillaria carioca de Freitas and lent, 1935; Moravec F. 1987; Capillaria catenata van Cleave and Mueller, 1932, and Capillaria petruschewski (Schulzman, 1948); and Capillaria gracile (Bellingham, 1844) Nikolaeva and Naidenova, 1964; Capillaria kabatai. Inglis and Coles, 1963;

Capillaria cyprinodonticola Huffman D.G, Bullock W.L. 1973; in the presence of well sclerotized spicules and absence of vulvar appendages. The present new form also differs from the following known forms in the following characters :-

1) Size of spicules and spicules length.

2) Vulva position,

3) Position of excretory pore ,

4) Structure of tail. The present species shows resemblences to Capillaria cichlasomae; Capillaria schmidtii but differs in the position of spicules, length of body etc.

\section{Conclusion:}

In the light of above discussion it is therefore, concluded that the present form is new to the genus Capillaria Zeder, 1800 and a new species Capillaria striata is erected. 


\section{Acknowledgement:}

We are thankful to the Principal of Govt. E.R.R. P.G. Science College, Bilaspur (C.G.) \& Head of the Zoology Department for helping me in every step to do this work \& for providing Laboratory facilities.

\section{Reference:}

HUFFMAN D.G., BULLOCK W.L. 1973 Capillaria cyprinodanticola sp. n, (Nematoda : Trichinellida) from the liver of Cyprinodontiform fishes of the Florida Keys. J. Parasitol. 59 : 260-263.

MORAVEC F. 1987: Revision of Capillariid nematodes (SubfamilyCapillariinae) parasitic in fishes studie CSAV No. 3, Academia, Parague, $141 \mathrm{pp}$.

MORAVEC F., T. Scholz \& E. Mendoza Franco 1993 : Capillaria

(Hepatocapillaria) cichlasomae sp.n., (Nematoda: Trichinellida) from the livers of the cichlid fish cichlasoma urophthalmus from Yucatan, Mexico.

Table (Comparison of Capillaria striata n.sp. with some known forms) All measurements are taken in $\mathrm{mm}$ otherwise stated.

\begin{tabular}{|c|c|c|c|}
\hline \multicolumn{4}{|l|}{$\underline{\text { Male }}$} \\
\hline Characters & C.cichlasomae & C.schmidtii & C.striata n.sp. \\
\hline Length & 1.83 & $8.40-10.12$ & $10.9-11.2$ \\
\hline Thickness & 0.030 & $0.07-0.08$ & $2.1-2.3$ \\
\hline Oesophagus $\mathrm{M}$ & 0.138 & $0.270-0.287$ & $1.7-1.9$ \\
\hline $\mathrm{G}$ & & $5.83-7.41$ & $1.9-2.2$ \\
\hline Nerv ring & 0.050 & $0.09-0.12$ & $1.2-1.4$ \\
\hline Spicules & 0.068 & $0.08-0.092$ & $1.3-1.4$ \\
\hline Papillae & - & - & - \\
\hline Tail & 0.008 & $0.010-0.012$ & $1.7-1.9$ \\
\hline \multicolumn{4}{|l|}{ Female } \\
\hline Length & 4.54 & $11.02-15.43$ & $14.2-14.7$ \\
\hline Thickness & 0.050 & $0.10-0.13$ & $2.7-3.1$ \\
\hline Oesophagus $\mathrm{M}$ & 0.195 & $0.310-0.324$ & $1.9-2.3$ \\
\hline $\bar{G}$ & & $6.52-9.38$ & $2.4-2.7$ \\
\hline Nerv ring & 0.075 & $0.11-0.12$ & $1.4-1.7$ \\
\hline Distt. of Value & 0.098 & $0.024-0.084$ & $2.00-2.1$ \\
\hline Tail & 0.008 & $0.015-0.018$ & $1.2-1.5$ \\
\hline
\end{tabular}

